\title{
PENGARUH COUNTRY OF ORIGIN DAN CELEBRITY ENDORSER TERHADAP KEPUTUSAN PEMBELIAN SMARTPHONE VIVO MELALUI CITRA MEREK SEBAGAI VARIABEL INTERVENING (STUDI KASUS PADA MAHASISWA UNIVERSITAS SARJANAWIYATA TAMANSISWA)
}

\author{
Bagas Ponco Kinasih \\ Fakultas Ekonomi Universitas Sarjanawiyata Tamansiswa Yogyakarta \\ bagasponco739@gmail.com \\ 085229614912
}

\begin{abstract}
Intisari
Penelitian ini memiliki tujuan untuk mengetahui (1) pengaruh country of origin pada citra merek, (2) pengaruh celebrity endorser pada citra merek (3) pengaruh country of origin pada keputusan pembelian (4) pengaruh celebrity endorser pada keputusan pembelian (5) pengaruh citra merek pada keputusan pembelian, (6) pengaruh country of origin terhadap keputusan pembelian melaui citra merek sebagai variabel intervening dan (7) pengaruh celebrity endorser terhadap keputusan pembelian melaui citra merek sebagai variabel intervening.

Dalam penelitian ini populasi yang digunakan 100 orang mahasiswa pengguna smartphone VIVO di Universitas Sarjanawiyata Tamansiswa Yogyakarta. Untuk metode pengumpulan data responden menggunakan metode kuesioner yang didistribusikan menggunakan teknik Accidental Purposive Sampling. Sedangkan teknik uji menggunakan uji T, uji F, Uji Sobel, dan Koefisien determinasi. Sedangkan untuk asumsi klasik terdiri dari uji normalitas, uji multikolinieritas, dan uji heterokedastisitas.
\end{abstract}

Hasil penelitian menunjukkan bahwa variabel country of origin berpengaruh terhadap citra merek, celebrity endorser berpengaruh terhadap citra merek, country of origin tidak berpengaruh terhadap keputusan pembelian, celebrity endorser tidak berpengaruh terhadap keputusan pembelian, citra merek berpengaruh terhadap keputusan pembelian.

Kata kunci: Country of Origin, Celebrity Endorser, Citra Merek, Keputusan Pembelian

\begin{abstract}
This study aims to determine (1) the influence of country of origin on brand image (2) the influence of celebrity endorser on brand image (3) the influence of country of origin on purchasing decisions (4) the influence of celebrity endorser on purchasing decisions (5) the influence of brand image on buying decision.
\end{abstract}

In this study the population was 100 students from Sarjanawiyata Tamansiswa University, Yogyakarta VIVO smartphone users. The data collection method uses a questionnaire method that is distributed using the Accidental Purposive Sampling technique. Whereas the T test technique and classic assumptions consisting of normality test, multicollinearity test, and heterokesdasticity test.

The results showed that the country of origin variable influenced the brand image, celebrity endorser affected the brand image, country of origin did not affect the purchasing decision, celebrity endorser did not affect the purchasing decision, brand image influenced the purchasing decision.

Keywords: Country of Origin, Celebrity Endorser, Brand Image, Purchasing Decision 


\section{PENDAHULUAN}

Era globalisasi pada saat ini merupakan zaman dimana perkembangan teknologi memiliki kemajuan pesat, kemajuan tersebut tergambarkan dengan semakin banyaknya teknologi-teknologi yang bermunculan. Teknologi yang hadir dan mengalami kemajuan yang pesat diantaranya yaitu handphone, saat ini sudah menjadi bagian penting dari keseharian masyarakat di Indonesia.

Kegunaan handphone pada saat ini tidak hanya sebatas alat untuk berkomunikasi saja, namun sudah menjadi alat yang multifungsi, seperti menjadikan media hiburan, dan dapat membantu dalam melakukan pekerjaan. Perubahan kemajuan yang pesat ini membawa pada perubahan penyebutan handphone menjadi ponsel pintar atau smartphone. Dengan pergeseran penyebutan tersebut menjadikan smartphone sebagai alat komunikasi yang memiliki banyak keunggulan yang tidak dimiliki oleh handphone.

Saat ini produsen smartphone selalu memberikan pembaruan dan penyegaran pada produkproduk yang dihasilkan agar sesuai dengan perkembangan zaman dan tidak tertinggal oleh para pesaingnya. Ketatnya persaingan smartphone di Indonesia ini didukung oleh survei yang dilakukan Pew Research Center, dari semua orang dewasa pemilik HP di Indonesia, 42 persennya pengguna smartphone, pada pemakai usia muda (18-34 tahun) kepemilikan smartphone mengalami kenaikan dari 39 persen menjadi 66 persen dalam waktu 2015-2018. Sedangkan untuk pengguna smartphone untuk usia di atas 50 tahun juga mengalami kenaikan dari 2 persen pada tahun 2015 menjadi 13 persen di tahun 2018. Lalu 28 persen memiliki HP biasa, dan 29 persen tidak mempunyai HP (tekno.temo.co, 2019).

Adanya peluang tersebut dimanfaatkan oleh smartphone VIVO, VIVO adalah sebuah perusahaan elektronika asal Dongguan, Guangdong, Tiongkok (China) yang berdiri pada tahun 2009 (wikipedia, 2016). Riset yang dikeluarkan oleh International Data Corporation (IDC) pada kuartal pertama (Q1) 2019. VIVO mampu memasuki jajaran lima besar, VIVO berhasil mendongkrak jumlah penjualan sebanyak 24 persen dari 18,7 juta pada Q1 2018, menjadi 23,2 juta unit pada Q1 2019, dalam waktu tujuh tahun VIVO mampu berada di jajaran Top 5 Company Shipments (tekno.compas.com, 2019). Perkembangan yang diraih smartphone VIVO menjadikan VIVO memiliki market share di Indonesia.

\section{TINJAUAN PUSTAKA DAN PENGEMBANGAN HIPOTESIS}

Country of Origin adalah asosiasi mental dan keyakinan yang dipicu oleh suatu negara (Ghaizani A., Pangestuti, \& Rahma Devita, 2018). Country of origin dapat menggunakan 3 komponen berikut. (1) Country Beliefs, keyakinan calon konsumen tentang pembangunan industri dan kemajuan teknologi di negara asal merek suatu produk. (2) People Affect, tanggapan afektif dari calon konsumen kepada masyarakat negara asal merek suatu produk. (3) Desired Interaction, kesediaan atau kemauan calon konsumen untuk bersinergi dengan negara asal merek suatu produk.

Celebrity Endorser merupakan penggunaan artis sebagai endorser dalam berbagai media cetak, media sosial, dan media elektronik (Pertiwi, 2019). Atribut dalam endorser. (1) Credibility, endorser yang memiliki keahlian akan dipercaya melakukan persuasi dibandingkan dengan yang kurang memiliki kemampuan dan kurang dapat dipercaya. (2) Attractiveness, endorser yang memiliki tampilan fisik atau nonfisik yang dapat memberikan nilai plus memberikan dampak kepada konsumen sehingga dinilai menarik dan dapat menunjang iklan. (3) Power, power adalah karisma yang dimiliki oleh narasumber untuk dapat memberikan pengaruhi kepada konsumen, sehingga konsumen sebagai sasarannya dapat terpengaruh untuk membeli produk.

Citra Merek yaitu kumpulan asosiasi merek yang didasari oleh berbagai ketertarikan yang dikembangkan oleh konsumen pada setiap waktu, brand seperti manusia dapat berupa gagasan yang mempunyai masing-masing personality (Cholifah, Suharyono, \& Hidayat, 2016). 3 komponen pendukung citra merek, yaitu : (1) Citra pembuat, seluruh pandangan pelanggan kepada perusahaan sebagai produsen. (2) Citra pemakai, seluruh pandangan 
pelanggan terhadap konsumen produk. (3) Citra produk, keseluruhan persepsi pelanggan terhadap produk.

Keputusan pembelian merupakan bagaimana seorang konsumen memilih dan melakukan pembelian dari beberapa pilihan dan alternatif yang telah dia pilih berdasarkan halhal tertentu. (Wijanarko, Suharyono, \& Arifin, 2016). 5 komponen pengambilan keputusan yaitu : (1) Menganalisis kebutuhan dan keinginan, berusaha mengetahui adanya kebutuhan dan keinginan yang belum terpenuhi atau terpuaskan. (2) Pencarian informasi dan penilaian sumber-sumber, pencarian informasi tentang sumber-sumber dan menilainya. (3) Penilaian dan seleksi alternatif pembelian, menetapkan tujuan untuk membeli dan menilai serta menyeleksi terhadap alternative pembelian berdasarkan tujuan pembeliannya. (4) Keputusan untuk membeli, mengambil keputusan apakah membeli atau tidak. Berikutnya akan membeli merk tersebut lagi, dan begitu pula sebaliknya. (5) Perilaku sesudah pembelian, berpengaruh terhadap penjualan ulang dan juga mempengaruhi ucapan-ucapan pembeli kepada pihak lain tentang produk perusahaan.

\section{PENGEMBANGAN HIPOTESIS}

\section{Country of Origin terhadap Citra Merek}

Country of origin memiliki pengaruh positif dan signifikan terhadap citra merek, sejalan dengan penelitian yang dilakukan (Suria, Kusumawati, \& Pangestuti, 2016). Variabel country of origin berpengaruhi signifikan terhadap citra merek, dan semakin baik persepsi konsumen terhadap country of origin suatu merek, maka semakin positif citra merek tersebut H1 : Country of Origin dapat mempengaruhi secara positif dan signifikan terhadap Citra Merek.

\section{Celebrity Endorser terhadap Citra Merek}

Celebrity endorser memiliki pengaruh positif dan signifikan terhadap citra merek, sejalan dengan penelitian yang dilakukan (Wijanarko, Suharyono, \& Arifin, 2016). Penelitian yang dialakukannya terdapat pengaruh korelasi positif celebrity endorser terhadap citra merek dan signifikan karena celebrity endorser mempengaruhi variabel citra merek.

$\mathrm{H} 2$ : Celebrity Endorser dapat mempengaruhi secara positif dan signifikan terhadap Citra Merek.

\section{Country of Origin terhadap Keputusan Pembelian}

Country of origin memiliki pengaruh positif dan signifikan terhadap keputusan pembelian, hal ini sejalan dengan penelitian yang dilakukan (Utama Putra, Suharyono, \& Mawardi, 2016) variabel country of origin memiliki pengaruh yang signifikan terhadap keputusan pembelian smartphone Xiaomi..

H3 : Country of Origin dapat mempengaruhi secara positif dan signifikan terhadap Keputusan Pembelian.

\section{Celebrity Endorser terhadap Keputusan Pembelian}

Celebrity endorser memiliki pengaruh positif dan signifikan terhadap keputusan pembelian, hal ini sejalan dengan penelitian yang dilakukan (Bramantya \& Jatra, 2016). Celebrity endorser berpengaruh terhadap keputusan pembelian.

H4 : Celebrity Endorser dapat mempengaruhi secara positif dan signifikan terhadap Keputusan Pembelian.

\section{Citra Merek terhadap Keputusan Pembelian}

Citra merek memiliki pengaruh positif dan signifikan terhadap keputusan pembelian, hal ini sejalan dengan penelian yang dilakukan oleh (Suria, Kusumawati, \& Pangestuti, 2016). Citra merek mempengaruhi secara signifikan terhadap keputusan pembelian.

H5 : Citra Merek dapat mempengaruhi secara positif dan signifikan terhadap Keputusan Pembelian. 


\section{METODE PENELITIAN}

Penelitian ini adalah penelitian yang bersifat kuantitatif. Populasi dalam penelitian ini merupakan mahasiswa \& mahasiswi yang berada dilingkungan kampus Universitas Sarjanawiyata Tamansiswa yang menggunakan produk smartphone VIVO. Untuk menentukan ukuran sampel menggunakan rumus $20 \mathrm{x}$ jumlah variabel yang diteliti, dalam penelitian ini menggunakan 4 variabel. Maka untuk menentukan ukuran sampel $20 \mathrm{x} 4=80$ (Sugiyono, 2013). Untuk mengantisipasi adanya kesalahan dan kuesioner rusak atau tidak kembali maka digenapkan menjadi 100 sampel.

\section{HASIL DAN PEMBAHASAN}

Berdasarkan Tabel 1 menunjukan bahwa rata-rata usia pengguna smartphone VIVO di kalangan mahasiswa Universitas Sarjanawiyata Tamansiswa Yogyakarta berusia 21 tahun dengan angka presentase 35\%. Dan menunjukkan bahwa dari 100 responden mahasiswa Universitas Sarjanawiyata Tamansiswa Yogyakarta yang menggunakan VIVO, pengguna di dominasi oleh perempuan dengan presentase $63 \%$.

Tabel 1. Usia \& Jenis Kelamin Responden

\begin{tabular}{cccccc}
\hline Usia & Frekuensi & Presentase & $\begin{array}{c}\text { Jenis } \\
\text { Kelamin }\end{array}$ & Frekuensi & Presentase \\
\hline 18 tahun & 2 & $2 \%$ & Laki-laki & 37 & $37 \%$ \\
19 tahun & 11 & $11 \%$ & Perempuan & 63 & $63 \%$ \\
20 tahun & 19 & $19 \%$ & & & \\
21 tahun & 35 & $35 \%$ & & & \\
22 tahun & 21 & $21 \%$ & & \\
23 tahun & 7 & $7 \%$ & & \\
24 tahun & 2 & $2 \%$ & & \\
25 tahun & 3 & $3 \%$ & & \\
\hline
\end{tabular}

Hasil uji validitas Tabel 2 menunjukkan nilai corrected item-total correlation $>$ dari $r$ table $(0,196)$ atau valid. Pengujian menghasilkan $\mathrm{r}$ hitung Country Of Origin $(0,383$ s.d. 0,696), Celebrity Endorser (0,562 s.d. 0,686), Citra Merek (0,512 s.d. 0,690), dan Keputusan Pembelian $(0,650$ s.d. 0,894) > 0,196. Cronbach's Alpha Stand. Country of Origin $(0,784)$, Celebrity Endorser (0,837), Citra Merek (0,821), dan Keputusan Pembelian $(0,956)>0,7$.

Tabel 2. Uji Validitas dan Reliabilitas

\begin{tabular}{|c|c|c|c|c|c|c|c|}
\hline \multicolumn{2}{|c|}{$\begin{array}{l}\text { Country of } \\
\text { Origin }\end{array}$} & \multicolumn{2}{|c|}{$\begin{array}{l}\text { Celebrity } \\
\text { Endorser }\end{array}$} & \multicolumn{2}{|c|}{ Citra Merek } & \multicolumn{2}{|c|}{$\begin{array}{l}\text { Keputusan } \\
\text { Pembelian }\end{array}$} \\
\hline $\mathrm{CO} 1$ & 0,383 & CE1 & 0,609 & CM1 & 0,547 & KP1 & 0,776 \\
\hline $\mathrm{CO} 2$ & 0,493 & CE2 & 0,599 & CM2 & 0,512 & KP2 & 0,780 \\
\hline $\mathrm{CO} 3$ & 0,587 & CE3 & 0,630 & CM3 & 0,650 & KP3 & 0,650 \\
\hline $\mathrm{CO} 4$ & 0,407 & CE4 & 0,590 & CM4 & 0,690 & KP4 & 0,686 \\
\hline $\mathrm{CO} 5$ & 0,696 & CE5 & 0,686 & CM5 & 0,515 & KP5 & 0,834 \\
\hline \multirow[t]{5}{*}{$\mathrm{CO} 6$} & 0,663 & CE6 & 0,562 & CM6 & 0,598 & KP6 & 0,841 \\
\hline & & & & & & KP7 & 0,877 \\
\hline & & & & & & KP8 & 0,860 \\
\hline & & & & & & KP9 & 0,888 \\
\hline & & & & & & KP10 & 0,894 \\
\hline \multicolumn{8}{|c|}{ Cronbach's Alpha Based on Standardized Items } \\
\hline \multicolumn{2}{|c|}{0,784} & \multicolumn{2}{|c|}{0,837} & \multicolumn{2}{|c|}{0,821} & \multicolumn{2}{|c|}{0,956} \\
\hline
\end{tabular}

Tabel 3 menunjukkan model regresi tidak mengalami multikolonieritas (tolerance > 0,10 dan VIF < 10), tidak mengalami heteroskedastisitas dan data terdistribusi normal 
(Kolmogorov-Smirnovtest memiliki asymp sig > 0,05). Dengan demikian ketiga model regresi memenuhi persyaratan untuk diuji regresi.

Tabel 3. Asumsi Klasik Tahap I

\begin{tabular}{ccccccc}
\hline Mdl. & \multicolumn{2}{c}{ Variabel } & Normalitas & Heteroskedastisitas & \multicolumn{2}{c}{ Multikolonieritas } \\
\hline & Bebas & Terikat & Sig. & Sig. & Tol. & VIF \\
\hline \multirow{2}{*}{1} & CO & & \multirow{2}{*}{0,997} & 0,433 & 0,519 & 1,928 \\
& CE & CM & \multirow{2}{*}{0,215} & 0,519 & 1,928 \\
& & & & & & \\
\hline \multirow{2}{*}{2} & CO & \multirow{2}{*}{ KP } & \multirow{2}{*}{0,108} & 0,089 & 0,455 & 2,196 \\
& CE & KP & \multirow{2}{*}{0,832} & 0,445 & 2,249 \\
& CM & & & 0,968 & 0,501 & 1,996 \\
\hline
\end{tabular}

Hasil pada Tabel 4 pengujian hipotesis menunjukkan bahwa H1 diterima karena memiliki nilai yang positif dan signifikan 3,669 dan 0,000<0,05. Dan H2 diterima karena memiliki nilai yang positif dan signifikan 4,021 dan $0,000<0,05$. H3 ditolak karena nilai positif dan tidak signifikan 0,613 dan 0,541 >0,05. H4 ditolak karena nilai yang positif dan tidak signifikan 1,430 dan $0,156>0,05$. Dan H5 diterima karena nilai yang positif dan signifikan 6,512 dan 0,000<0,05. Pengaruh Country of Origin dan Celebrity Endorser terhadap Keputusan Pembelian memiliki adjusted $R$ square sebesar 48,9\%, sisanya 51,1\% dipengaruhi faktor lain diluar model penelitian ini. Pengaruh Country of Origin, Celebrity Endorser dan Citra Merek terhadap Keputusan Pembelian memiliki adjusted $R$ square sebesar 56,1\%, sisanya 43,9\%\% dipengaruhi faktor lain diluar model penelitian ini.

Tabel 4. Pengujian Hipotesis

\begin{tabular}{|c|c|c|c|c|c|c|}
\hline \multirow[t]{2}{*}{ Hip. } & \multicolumn{2}{|c|}{ Variabel } & \multirow{2}{*}{$\frac{\text { Stand. Coeff. }}{\text { Beta }}$} & \multirow[b]{2}{*}{$T$} & \multirow[b]{2}{*}{ Sig. } & \multirow{2}{*}{$\begin{array}{c}\text { Koef. Detr. } \\
\text { Adj. } R \text { Sq }\end{array}$} \\
\hline & Bebas & Terikat & & & & \\
\hline $\mathrm{H} 1$ & $\mathrm{CO}$ & \multirow{2}{*}{$\mathrm{CM}$} & 0,366 & 3,669 & 0,000 & \multirow{2}{*}{0,489} \\
\hline $\mathrm{H} 2$ & $\mathrm{CE}$ & & 0,401 & 4,021 & 0,000 & \\
\hline H3 & $\mathrm{CO}$ & \multirow{3}{*}{$\mathrm{KP}$} & 0,060 & 0,613 & 0,541 & \multirow{3}{*}{0,561} \\
\hline $\mathrm{H} 4$ & $\mathrm{CE}$ & & 0,143 & 1,430 & 0,156 & \\
\hline $\mathrm{H} 5$ & $\mathrm{CM}$ & & 0,613 & 6,512 & 0,000 & \\
\hline
\end{tabular}

Berdasarkan pada Tabel 5 dapat diketahui nilai dari probabilitas pada $\mathrm{F}$ huitung adalah 0,000 atau lebih kecil dari 0,05 sehingga dapat dikatakan bahwa Ho ditolak. Hal tersebut berarti bahwa variabel independen yang digunakan yaitu country of origin (CO) dan celebrity endorser (CE) secara bersama-sama memiliki pengaruh terhadap variabel dependen citra merek (CM). Tabel 6 dapat dilihat nilai dari probabilitas pada $\mathrm{F}$ huitung adalah 0,000 atau lebih kecil dari 0,05 sehingga dapat dikatakan bahwa Ho ditolak. Hal tersebut berarti bahwa variabel independen yang digunakan yaitu country of origin (CO), celebrity endorser $(\mathrm{CE})$, citra merek $(\mathrm{CM})$ secara bersama-sama memiliki pengaruh terhadap variabel dependen keputusan pembelian (KP).

Tabel 5

Uji F (1)

\begin{tabular}{lll}
\hline Model & F & Sig. \\
\hline Regression & 48,299 & 0,000 \\
\hline
\end{tabular}

Tabel 6

Uji F (2)

\begin{tabular}{lll}
\hline Model & F & Sig. \\
\hline Regression & 43,124 & 0,000 \\
\hline
\end{tabular}




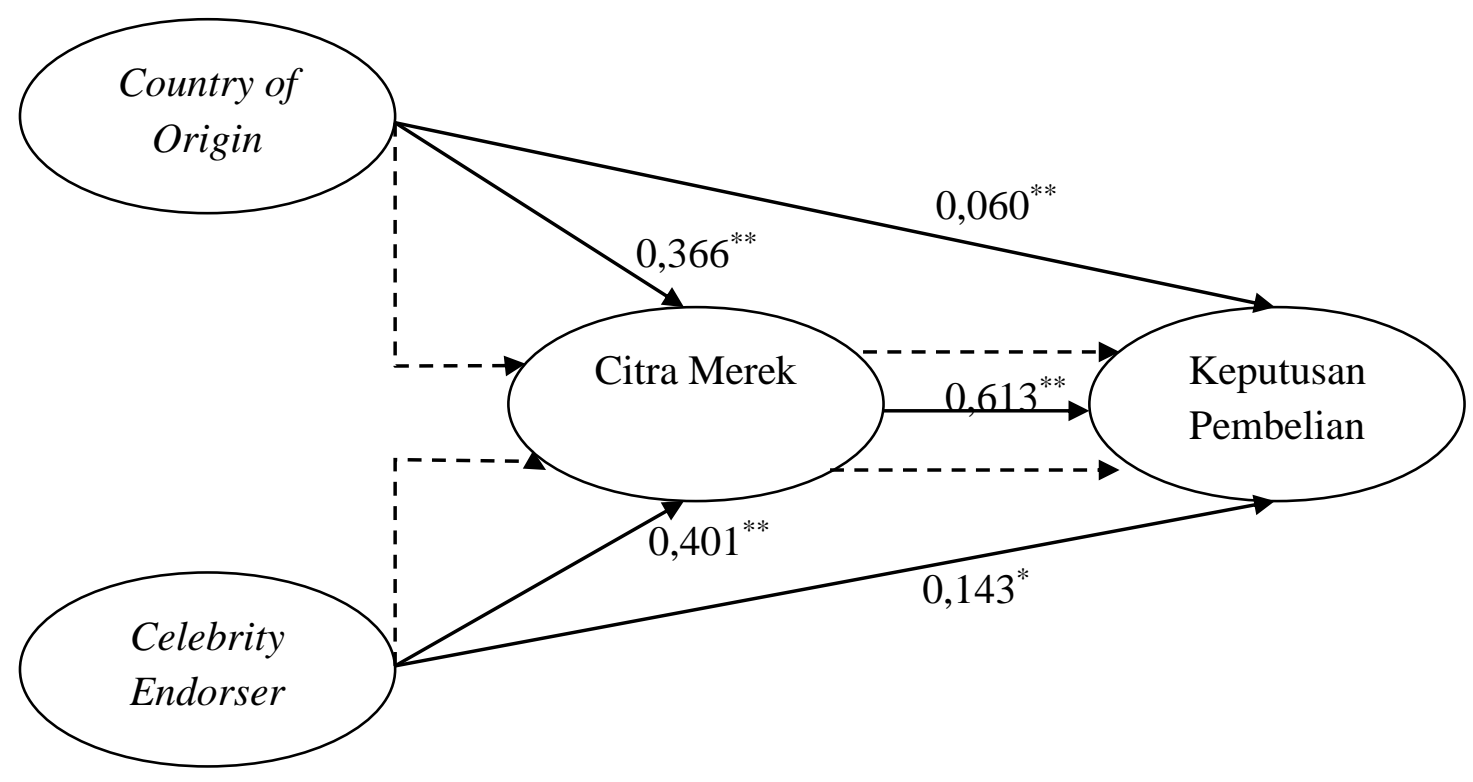

Gambar 1. Hasil Uji Hipotesis

Dari hasil perhitungan sobel tes pada Gambar 3 diketahui one-tailed probability $0,00070141<0,05$. Berdasarkan hasil perhitungan tersebut dapat disimpulan bahwa citra merek bisa menjadi variabel intervening antara country of origin dan keputusan pembelian. Serta membuktikan bahwa H6 yang menyebutkan country of origin berpengaruh terhadap keputusan pembelian melalui citra merek Diterima.

Dari hasil perhitungan sobel tes pada Gambar 4 diketahui one-tailed probability $0,00032134<0,05$. Berdasarkan hasil perhitungan tersebut dapat disimpulan bahwa citra merek bisa menjadi variabel intervening antara celebrity endorser dan keputusan pembelian. Serta membuktikan bahwa $\mathrm{H} 7$ yang menyebutkan celebrity endorser berpengaruh terhadap keputusan pembelian melalui citra merek Diterima.

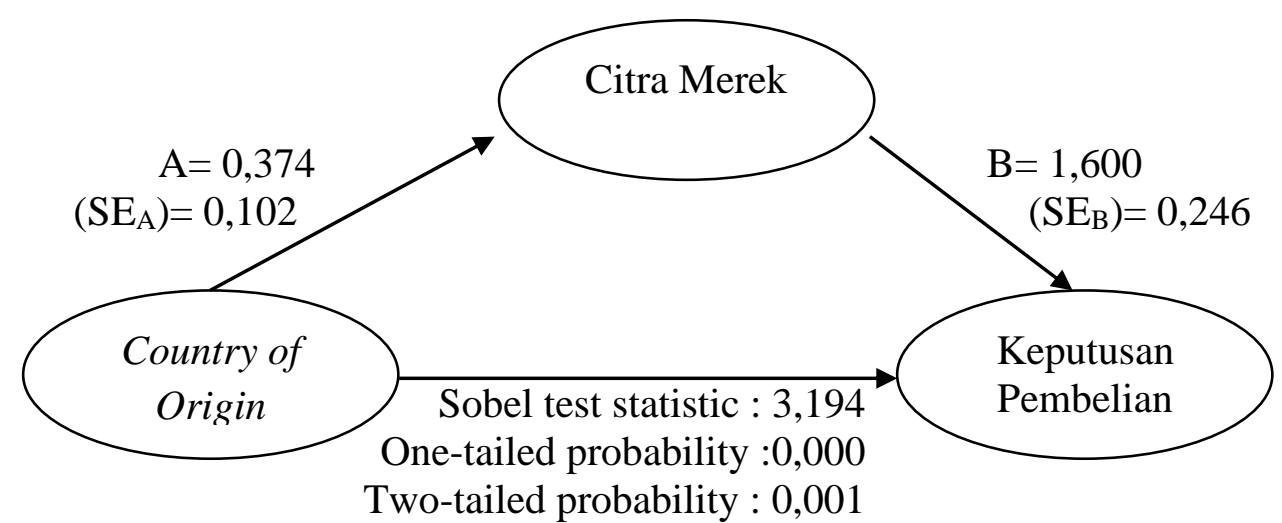

Gambar 2. Uji Sobel (1) 


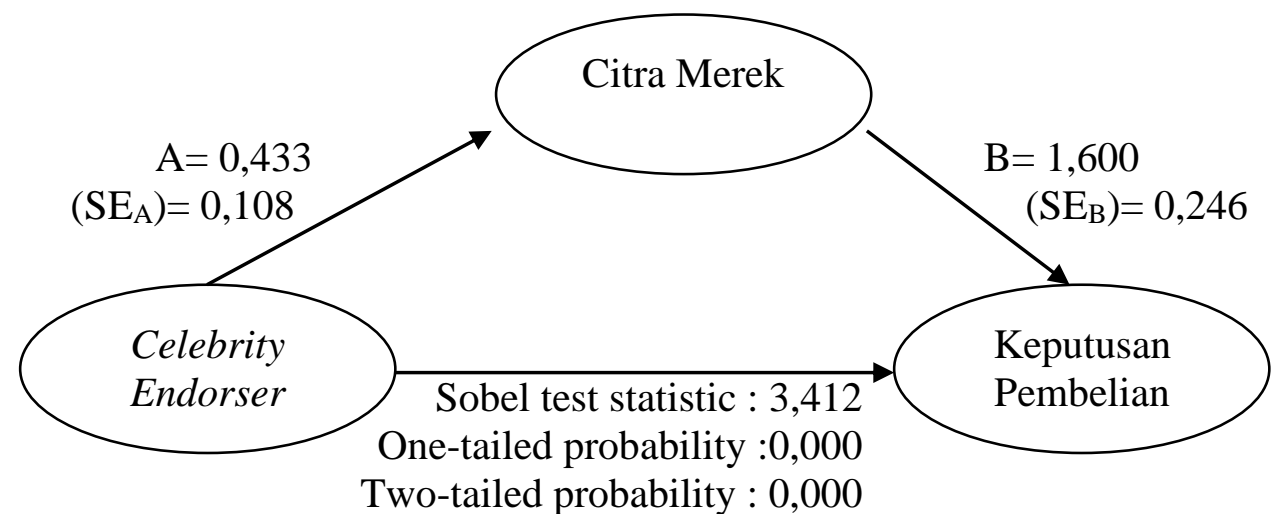

Gambar 3. Uji Sobel (2)

\section{PEMBAHASAN}

Berdasarkan dari uji parsial (t hitung) ini mengindikasikan country of origin berpengaruh positif dan signifikan terhadap citra merek smartphone VIVO pada mahasiswa Universitas Sarjanawiyata Tamansiswa Yogyakarta. Hasil dari penelitian menunjukkan bahwa tingkat perkembangan produk smartphone China mampu menyaingi produk dari negara kompetitornya. Dengan meningkatnya perkembangan produk smartphone VIVO menjadikan produk dari smartphone VIVO ini mudah dikenal di Indonesia.

Berdasarkan dari uji parsial ( $\mathrm{t}$ hitung) ini menunjukkan celebrity endorser berpengaruh positif dan signifikan terhadap citra merek smartphone VIVO pada mahasiswa Universitas Sarjanawiyata Tamansiswa Yogyakarta. Hasil penelitian ini menunjukkan bahwa celebrity endorser dalam iklan VIVO sesuai dengan target pasar yang diusung VIVO yaitu anak muda. Dengan sesuainya target pasar yang di usung oleh VIVO, maka membantu untuk memudahkan smartphone VIVO untuk dikenal di Indonesia.

Berdasarkan dari uji parsial ( $\mathrm{t}$ hitung) ini menunjukkan bahwa country of origin berpengaruh positif dan tidak signifikan terhadap keputusan pembelian smartphone VIVO pada mahasiswa Universitas Sarjanawiyata Tamansiswa Yogyakarta. Hasil dari penelitian tersebut menunjukkan bahwa masyarakat China belum mampu bersaing dengan negara lain dalam menciptakan produk berbasis teknologi tinggi. Dengan belum mampunya memproduksi produk dengan berbasis teknologi tinggi maka akan berdampak kepada konsumen yang memilih untuk membeli produk smartphone lain dibandingkan produk dari VIVO.

Berdasarkan dari uji parsial (t hitung) ini menunjukkan bahwa celebrity endorser berpengaruh positif dan tidak signifikan terhadap keputusan pembelian smartphone VIVO pada mahasiswa Universitas Sarjanawiyata Tamansiswa Yogyakarta. Hasil dari penelitian tersebut menunjukkan bahwa celebrity endorser yang digunakan dalam iklan VIVO belum tepat dan belum cocok untuk mengiklankan produk VIVO. Dengan belum tepatnya celebrity endorser yang dipilih oleh VIVO maka akan berdampak kepada konsumen yang lebih memilih untuk membeli produk smartphone lain dengan celebrity endorser yang tepat dibandingkan celebrity endorser yang digunakan oleh VIVO.

Berdasarkan dari uji parsial (t hitung) ini menunjukkan bahwa citra merek berpengaruh positif dan signifikan terhadap keputusan pembelian smartphone VIVO pada mahasiswa Universitas Sarjanawiyata Tamansiswa Yogyakarta. Hasil penelitian ini menunjukkan bahwa produk dari VIVO merupakan produk yang dikenal di Indonesia. Dengan mudahnya untuk mengenali produk VIVO ini didukung dengan mudahnya untuk mencari informasi tentang smartphone VIVO melalui media elektronik (web, online shop, web resmi VIVO). 
Pengaruh country of origin terhadap keputusan pembelian melalui citra merek sebagai variabel intervening menunjukkan bahwa citra merek berpengaruh dan mampu menjadi variabel intervening diantara country of origin terhadap keputusan pembelian. Hasil dari penelitian menunjukkan bahwa tingkat perkembangan produk smartphone China mampu menyaingi produk dari negara kompetitornya, dengan mampunya China menyaingi produk dari negara lain membuat produk VIVO mudah dikenal dan memiliki market share di Indonesia. Dengan sudah dikenalinya produk VIVO di Indonesia maka akan membuat smartphone VIVO mudah untuk dicari informasinya melalui media elektronik (web, online shop, web resmi VIVO).

Pengaruh celebrity endorser terhadap keputusan pembelian melalui citra merek sebagai variabel intervening menunjukkan bahwa citra merek berpengaruh dan mampu menjadi variabel intervening diantara celebrity endorser terhadap keputusan pembelian. Hasil penelitian ini menunjukkan bahwa celebrity endorser dalam iklan VIVO sudah sesuai dengan target pasar yang diusung VIVO yaitu anak muda., dengan sesuainya sasaran yang dipilih oleh pihak VIVO ini membuat produk dari VIVO mudah dikenal dan memiliki market share di kalangan anak-anak muda di Indonesia. Dengan sudah dikenalinya produk VIVO di Indonesia maka akan membuat smartphone VIVO mudah untuk dicari informasinya melalui media elektronik (web, online shop, web resmi VIVO).

\section{KESIMPULAN}

Berdasarkan hasil penelitian diatas maka dapat diambil kesimpulan bahwa variabel country of origin dan celebrity endorser tidak dapat berpengaruh secara signifikan terhadap keputusan pembelian. Variabel country of origin berpengaruh positif dan signifikan terhadap citra merek. Variabel celebrity endorser berpengaruh positif dan signifikan terhadap citra merek. Variabel citra merek berpengaruh positif dan signifikan terhadap keputusan pembelian. Variabel citra merek mempengaruhi hubungan country of origin terhadap keputusan pembelian. Variabel citra merek mempengaruhi hubungan country of origin terhadap keputusan pembelian.

\section{SARAN \\ Perusahaan}

Perusahaan VIVO yang berbasis di China ini harus benar-benar memilih karyawannya dengan tepat, guna dapat mengimbangi produksi dengan menggunakan teknologi yang lebih tinggi. Pemilihan celebrity endorser yang dilakukan oleh VIVO harus lebih selektif, guna penyampaian iklan dapat lebih menarik konsumen dan dapat meningkatkan penjualan. VIVO harus meningkatkan kegiatan iklannya melalui berbagai cara contohnya seperti menjadi sponsor dalam acara olah raga yang memiliki banyak peminat, dengan peminatnya yang banyak ini membuat produk-produk dari VIVO dapat dengan mudah dikenali oleh konsumen. VIVO sebagai salah satu perusahaan smartphone harus meningkatkan fitur yang ada di dalamnya, guna produknya dapat menjadi produk pilihan yang dipertimbangkan oleh konsumen untuk melakukan pembelian ulang.

\section{Peneliti}

Untuk kedepannya dapat menciptakan penelitian yang lebih baik dari penelitian ini dan diharapkan dapat menambah variabel yang lain supaya memiliki referensi yang lebih banyak dan lebih baik lagi.

\section{DAFTAR PUSTAKA}

Bramantya, Y. B., \& Jatra, M. (2016). Pengaruh Celebrity Endorser Dan Brand Image Terhadap Keputusan Pembelian Yamaha Jupiter Mx Di Kota Denpasar. E-Jurnal Manajemen Unud, 5, 1745-1771. 
Cholifah, N., Suharyono, \& Hidayat, K. (2016). Pengaruh Celebrity Endorser Terhadap Brand Image (Survei pada Konsumen Kosmetik Wardah di Counter Wardah Kota Malang). Jurnal Administrasi Bisnis (JAB), 36, 170-177.

Ghaizani A., A., Pangestuti, E., \& Rahma Devita, L. D. (2018). Pengaruh Country Of Origin Terhadap Brand Image Dan Dampaknya Bagi Keputusan Pembelian (Survei Online Pada Konsumen Skin Care Etude House di Indonesia). Jurnal Administrasi Bisnis (JAB), 58, 110118.

Pertiwi, L. R. (2019). Pengaruh Citra Merek Dan Celebrity Endorser Terhadap Keputusan Pembelian Produk Wardah Exclusive Matte Lipcream. Jurnal Ilmu Manajemen, 7, 307-315.

Purwanto, U. Y., \& Suharyono. (2018). Pengaruh Celebrity Endorser Terhadap Citra Merek Dan Dampaknya Pada Keputusan Pembelian (Survei kepada Konsumen Malang Strudel di Outlet Singosari, Kab. Malang). Jurnal Administrasi Bisnis (JAB), 56, 1-5.

Purwitasari, T., Yulianto, E., \& Wilopo. (2018). Pengaruh Merek Dan Negara Asal (Country Of Origin) Terhadap Keputusan Pembelian (Survei pada Mahasiwa pengguna Oppo atau Samsung smartphone di Fakultas Ilmu Administrasi Angkatan tahun 2013-2015). Jurnal Administrasi Bisnis (JAB), 61, 100-108.

Sugiyono. (2013). Statistika Untuk Penelitian. Bandung: ALFABETA.

Suparman, \& Arifin, R. (2017). Pengaruh Citra Merek, Citra Perusahaan, Dan Kualitas Produk Terhadap Keputusan Pembelian Smartphone Merek Samsung (Studi Pada Mahasiswa Fakultas Ekonomi Universitas Islam Malang). Jurnal Riset Manajemen, 124-135.

Suria, N. N., Kusumawati, A., \& Pangestuti, E. (2016). Pengaruh Country Of Origin Terhadap Citra Merek Dan Dampaknya Bagi Keputusan Pembelian. Jurnal Administrasi Bisnis (JAB), 38, $148-156$

tekno.compas.com. (2019). 5 Besar Penguasa Pasar Smartphone Dunia di Kuartal Pertama 2019. Retrieved from tekno.compas.com: https:/tekno.compas.com/read/2019/05/02/09180027/5besar-penguasa-pasar-smartphone-dunia-di-kuartal-pertama-2019.

tekno.temo.co. (2019). Survei Kepemilikan Smartphone, Indonesia Peringkat ke-24. (Y. Yanuar, Editor) Retrieved Oktober 22, 2019, from tekno.tempo.co: https://tekno.tempo.co/read/1181645/survei-kepemilikan-smartphone-indonesia-peringkat-ke$24 /$ full\&view $=$ ok.

Utama Putra, A. S., Suharyono, \& Mawardi, M. (2016). Pengaruh Country Of Origin Dan Price Terhadap Keputusan (Survei Terhadap Konsumen Xiaomi di Indonesia, Malaysia, Singapura dan Filipina). Jurnal Administrasi Bisnis (JAB), 40, 192-200.

Wijanarko, P., Suharyono, \& Arifin, Z. (2016). Pengaruh Celebrity Endorser Terhadap Citra Merek Dan Dampaknya Pada Keputusan Pembelian. Jurnal Administrasi Bisnis (JAB), 165-171.

wikipedia. (2016). Vivo. Retrieved Oktober 2, 2019, from WIKIPEDIA: https://id.m.wikipedia.org/wiki/Istimewa:History/Vivo 